Journal of Economics and Behavioral Studies

Vol. 6, No. 7, pp. 532-541, July 2014 (ISSN: 2220-6140)

\title{
Perceived Brand Personality of Symbolic Brands
}

\author{
RE-AN MÜLLER \\ North-West University Vaal-Triangle Campus, South Africa \\ Rean.Muller@nwu.ac.za
}

\begin{abstract}
Brand personality can be defined as a set of human characteristics associated with a brand (Aaker, 1997).This study reports on the perceived brand personality of symbolic brands as seen by Generation $Y$ students from one higher education institution campus located in South Africa. The respondents were asked to write down the first brand that came to mind for eight symbolic product categories. The top two brands in each category were used in a self-administered questionnaire. A second group of respondents were then asked to write down personality traits they associate with each of the identified brands. These findings, present a unique viewpoint regarding a number of brands and how the respondents perceive their brand personalities.
\end{abstract}

Keywords: Brand personality, symbolic brands, branding, marketing, high-involvement products

\section{Introduction}

"I love my Jeep because it is tough like me", a title of a paper by Govers and Mugge (2004) which illustrate a typical product-personality resemblance. Consumers search for brands with personalities that corresponds with theirs or brands that personalise who they want to become (Freling \& Forbes, 2005). This creates the challenge for businesses to create brands with specific personalities to appeal to various consumers. Marketers are interested in promoting a brand personality that attracts a consumer's attention (Mulyanegara, Tsarenko \& Anderson, 2009). The symbolic meaning that consumers attach to brands has become a major focus of marketing research (Austin, Siguaw \& Mattila, 2003). Aaker (1996) also acknowledge brand personality as one of the contributing factors towards brand equity. Marketing academicians and practitioners have long since been aware of the important influence that brand personality has on consumer behaviour (Opoko, Abratt \& Pitt, 2006). Ramaseshan and Tsao (2007) state that brand personality can increase consumers' preference for and usage of a brand, and result in stronger emotional ties and loyalty towards the brand. Brand personality also affects consumers' feelings, perceptions and attitudes (Freling \& Forbes, 2005). It also appeals to consumers and aids in building stronger relationships between an organisation and its target market(s) (Chang \& Lin, 2010). There is paucity of published research on consumers' perceptions of brand personality in the South African market. Heine (2010) mentions that there is a dearth of literature based on the symbolic meaning of luxury brands worldwide since his initial study (Heine, 2009), which he claims was the first to focus on the brand personality of luxury brands. This study of Heine's (2009) only focussed on a small sampling frame of millionaires within Germany, which suggests a definitive need for research on brand personality perception of typical consumers regarding symbolic products.

\section{Literature Review}

Ramaeseshan and Tsao (2007) describe brand personality as the soul of a brand that originates from the brand's characteristics and marketing communications. Various researchers (Freling \& Forbes, 2005; Opoko et al., 2006; Van Rekom, Jacobs, Verlegh \& Podnar, 2006) agree that the most widely accepted definition for brand personality is that of Aaker (1997), who states that brand personality refers to "a set of human characteristics assigned to a brand". Therefore, like humans, brands have personalities, and it is this personality dimension that sets them apart from their competitors (Freling \& Forbes, 2005). Personality traits are often used to communicate the positioning of a brand (Van Rekom et al., 2006). Brands function as entities with their own character traits. There are several examples of strong brand personalities in the market. Absolute Vodka is personified as a hip, cool, contemporary 25 years old, whereas Stoli's is personified 
as being a more intellectual and conservative older man (Aaker, 1997). The Honda Civic may be described as a rugby player in a dinner suit (Blythe, 2007). Apple is considered young while IBM is perceived as older (Aaker, 1997). These character traits could create emotional fulfilment for consumers, which may lead to brand loyalty (Freling \& Forbes, 2005).

Brand parity is typical in the market today and businesses need to differentiate themselves by means of symbolic benefits (Kapferer, 2008). Symbolic products may also be referred to as high involvement products. This type of product identification is based on the involvement theory. Consumers typically spend more time deciding on what brand to purchase due to the symbolic nature of such products (Shiffman \& Kanuk, 2010). Lamb, Hair, McDaniel, Boshoff, Terblanche, Elliott and Klopper (2010) argue that products like clothes and motor vehicles with a high social visibility will result in the buyer being more involved in the purchase. This might be due to the symbolic nature of the products. This higher involvement might lead to a greater focus on the brand personality depicted by the specific brand.

\section{Methodology}

This study consisted of two prominent steps. The empirical objective for step one was to determine the most prevalent brands that respondents associate with the identified symbolic product categories. Step two aimed to identify all the brand personality traits that respondents link to the brands identified in Step one.

Sampling methodology: Non-probability convenience samples will be taken from a sampling frame of students registered at one South African HEI campus located in the Gauteng Province. The proposed sample size for each step is as follows:

Step 1: This step included 52 respondents to identify the brand that first comes to mind when thinking of a specific symbolic product category.

Step 2: The identified brands was presented to 64 respondents. Each respondent was requested to list personality traits that came to mind when thinking of each of the identified brands.

Data collection: The measuring instrument, data collection method and data capture method for each step is as follows:

Step 1: The measuring instrument in this step was a self-administered questionnaire comprising of a list of eight symbolic product categories (takkies, jeans, beers, ciders, sunglasses, television sets, cellular phones and motor cars). Respondents were requested to write down the first brand that came to mind when thinking of each of the product categories.

Step 2: The results of Step 1 was used to select the top two brands for each of the product categories. These brands will be randomly placed in two questionnaires (each containing one brand from each product category) and administered to respondents, who will be asked to write down the personality traits they associate with each of the brands (respondents will be asked to think of the brands as if they were a person to whom they need to assign personality traits).

\section{Results}

The demographic distribution for each step follows: 


\section{Gender}
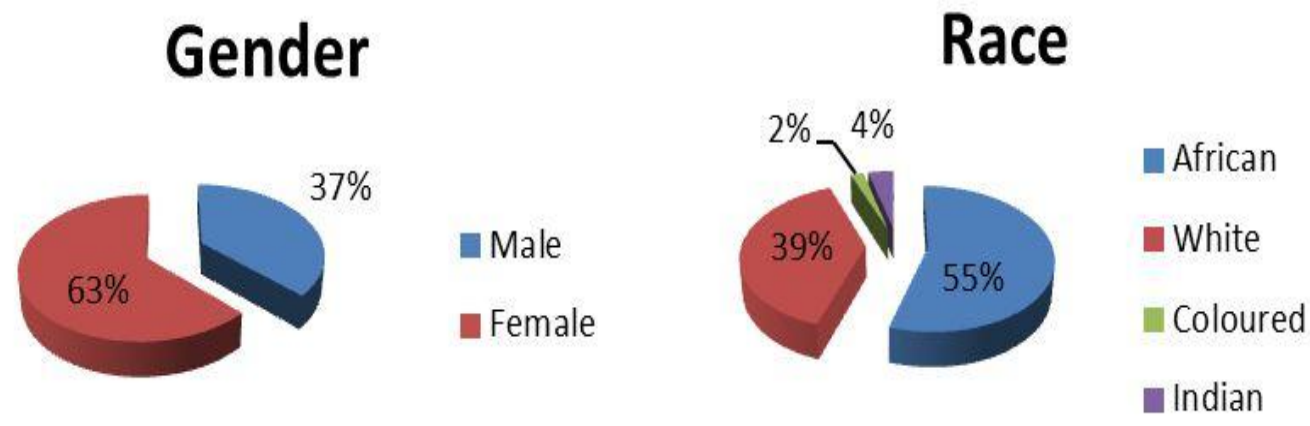

Figure 2: Demographic distribution of Step 2
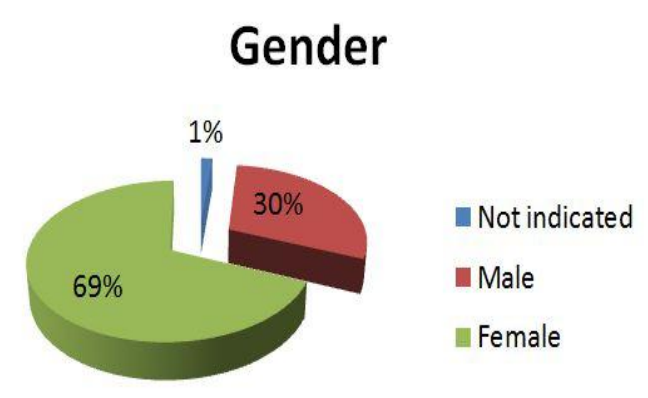

\section{Designated Group}

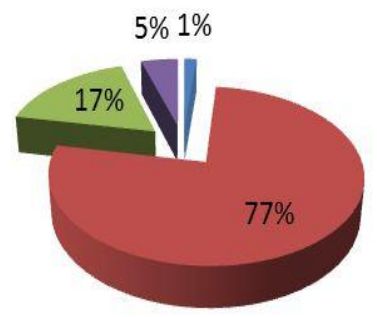

Not indicated

African

White

Coloured

The top 2 brands identified in Step 1 are depicted in Table 1.

Table 1: Top two brands in each symbolic product category

\begin{tabular}{lll}
\hline PRODUCT CATEGORY & NO. 1 BRAND & NO. 2 BRAND \\
\hline "Takkies" & Nike & Adidas \\
Jeans & Guess & Levi \\
Beer & Castle & Black Label \\
Cider & Red Square & Savanna \\
Sunglasses & Ray Ban & Police \\
Cellphone & Black Berry & Nokia \\
TV & Samsung & Sony \\
Car & BMW & Toyota \\
\hline
\end{tabular}

The personality traits identified for each brand by the respondents is depicted in Figure 3 to 18 . The researcher made use of an online tool: Wordle ${ }^{\mathrm{TM}}$ (www.wordle.net) to make "word clouds to illustrate the results. The larger the word is the more often it was used by respondents. 
Figure 3: Adidas "takkies"

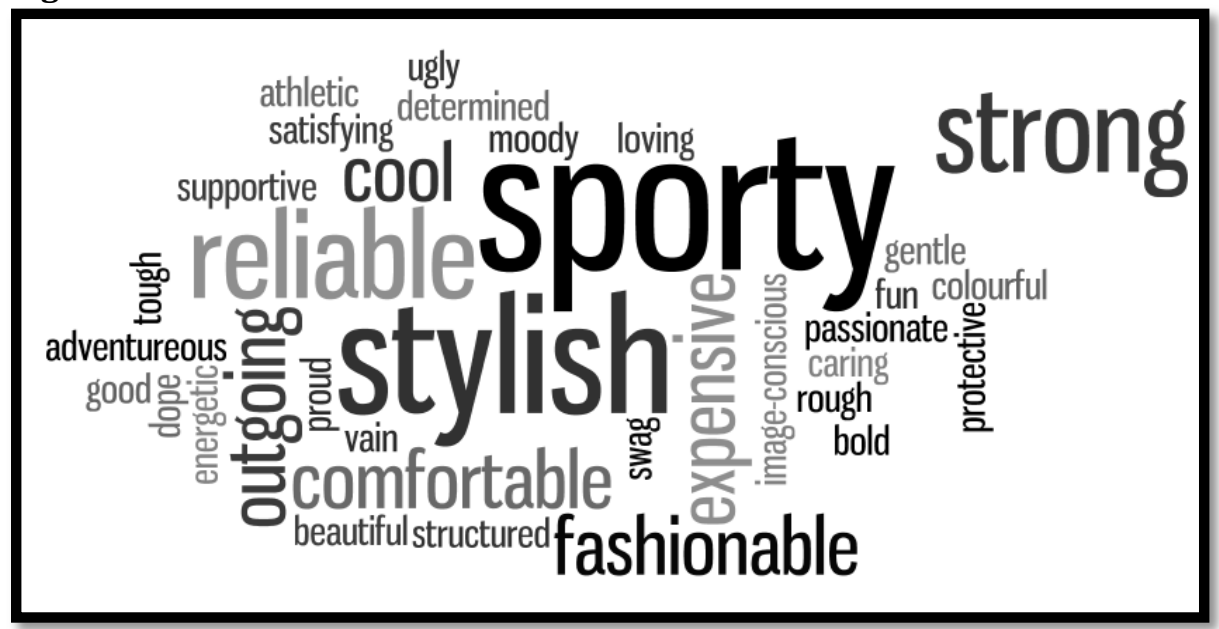

Figure 4: Nike “takkies"

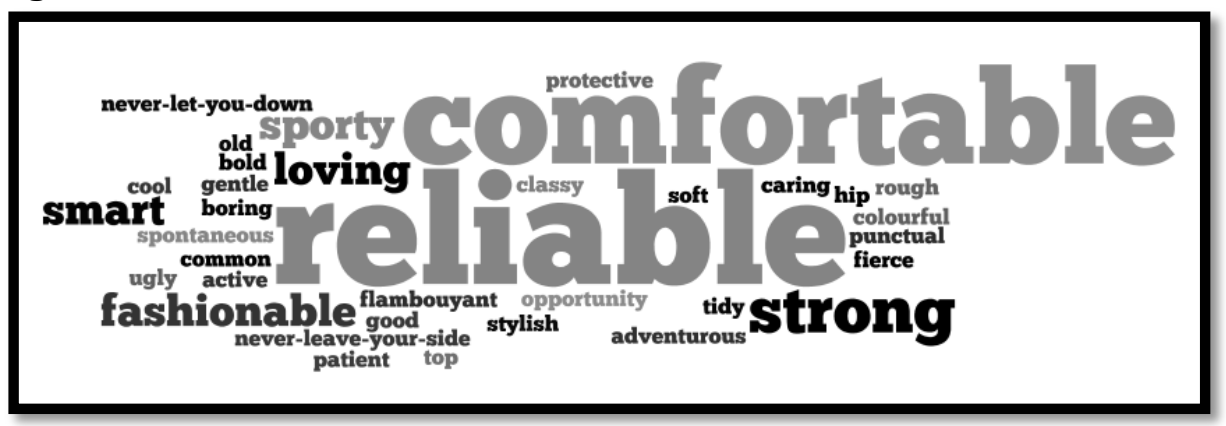

Figure 5: Levi jeans

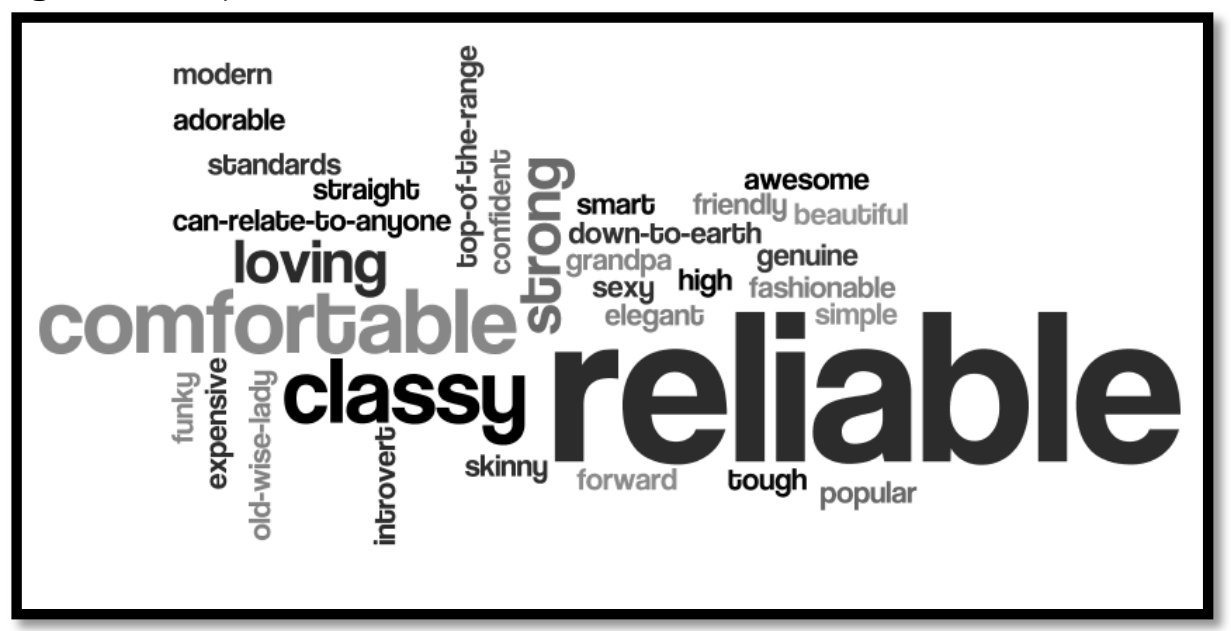


Figure 6: Guess jeans

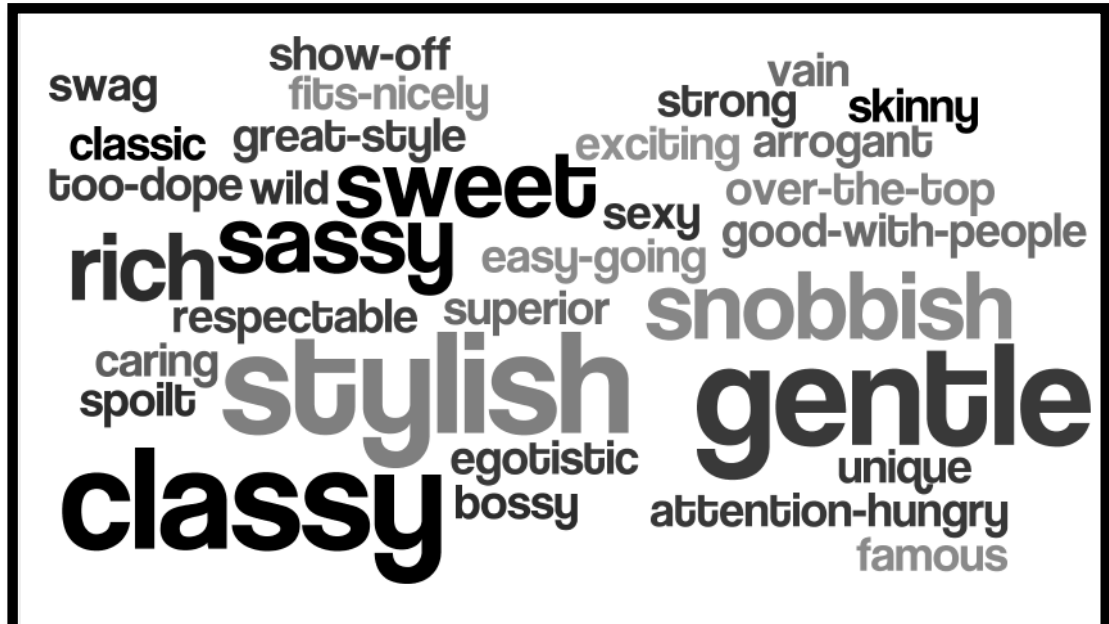

Figure 7: Black Label beer

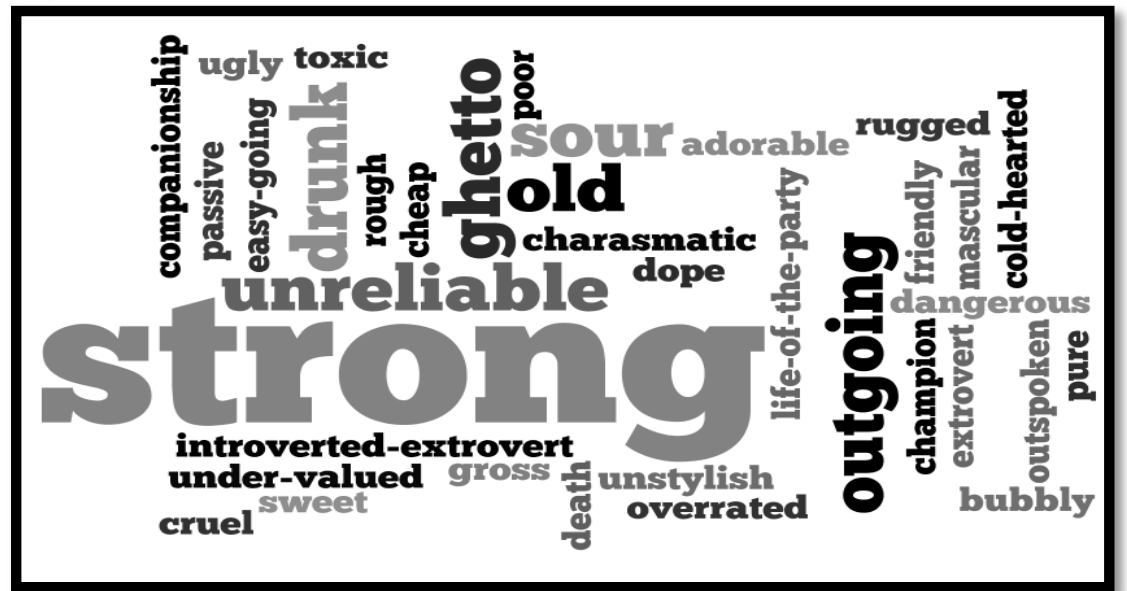

Figure 8: Castle Lager beer

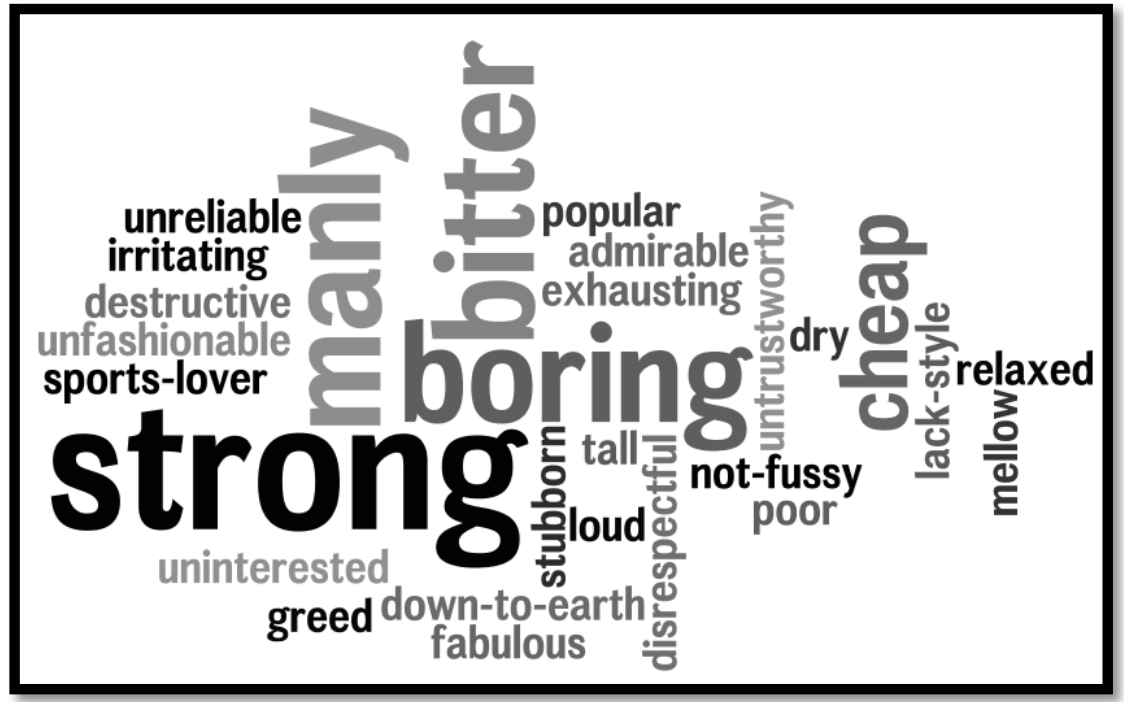


Figure 9: Savanna Cider

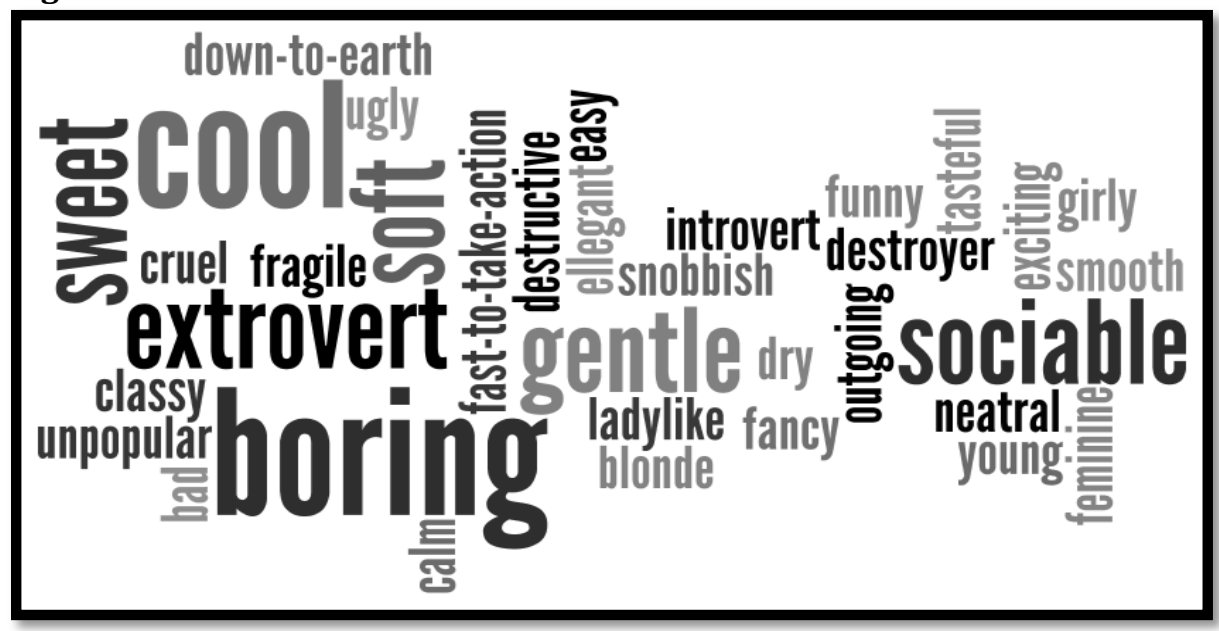

Figure 10: Red Square Cider

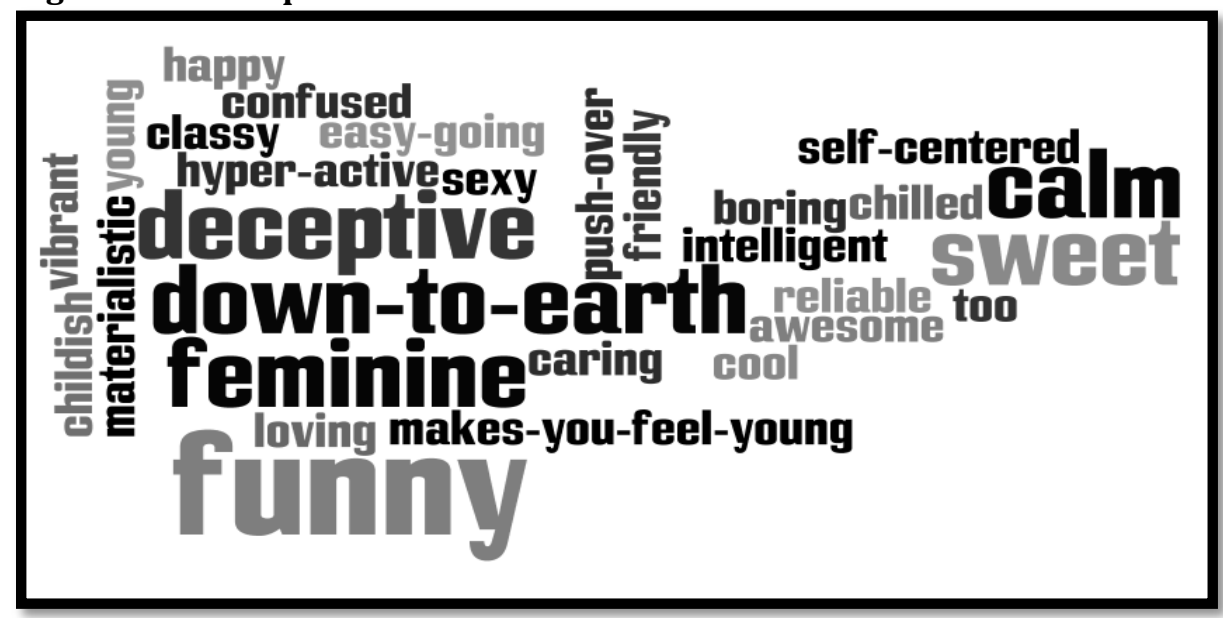

Figure 11: Rayban Sunglasses

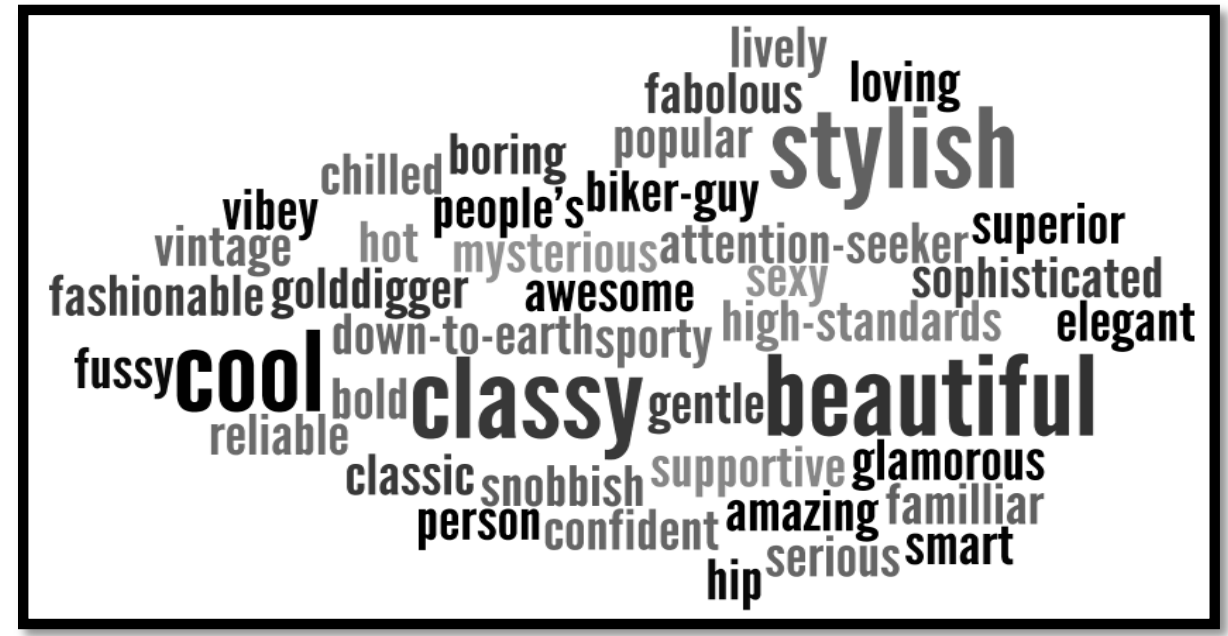




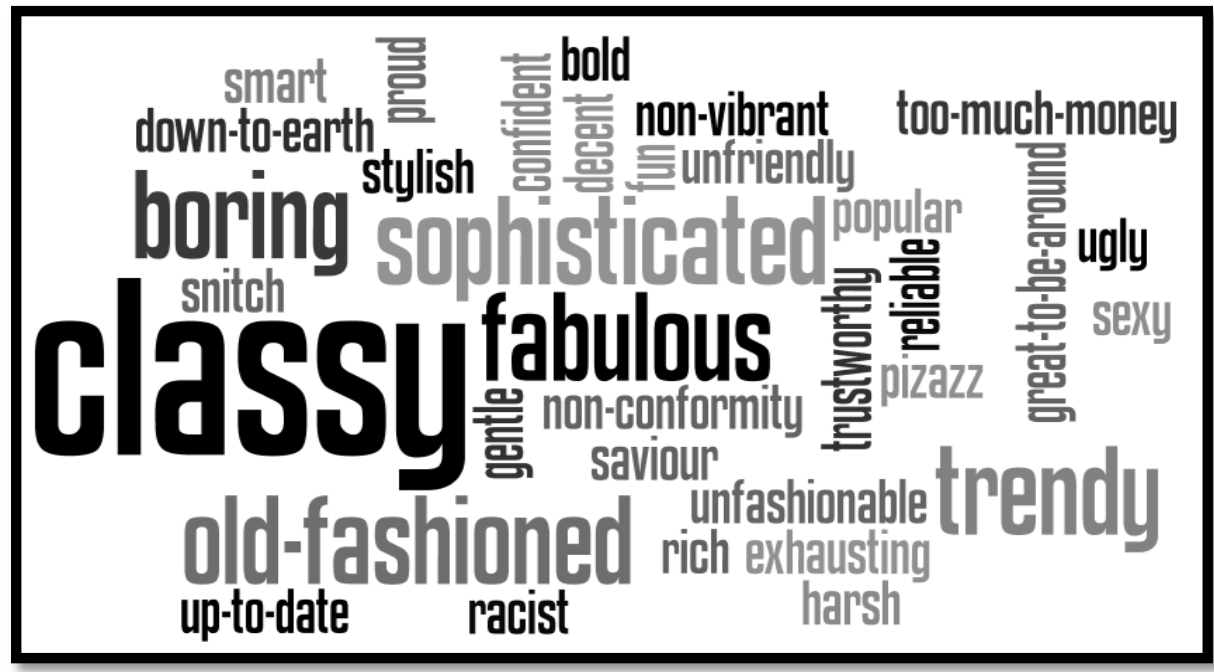

Figure 13: Blackberry

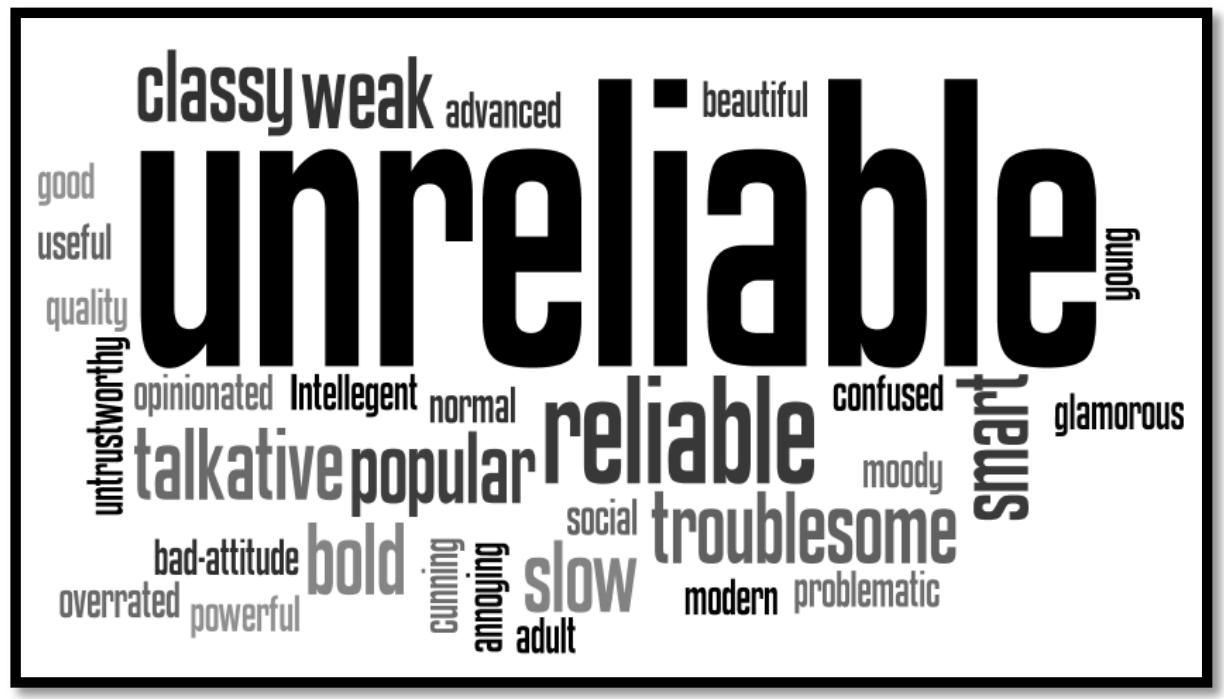

Figure 14: Nokia

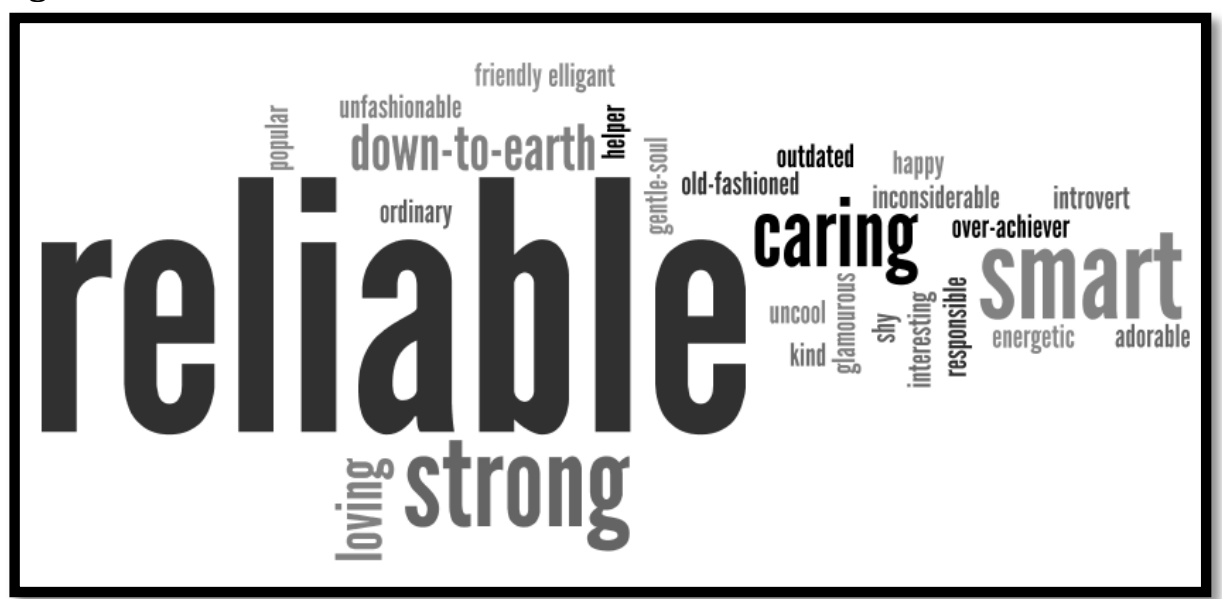




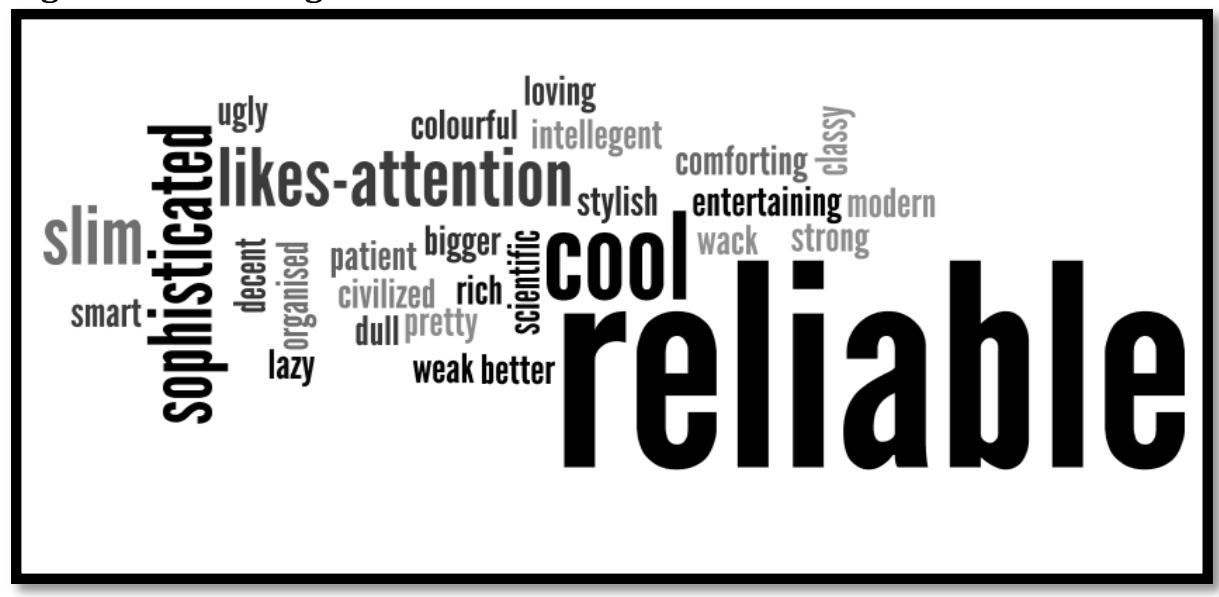

Figure 16: LG TV

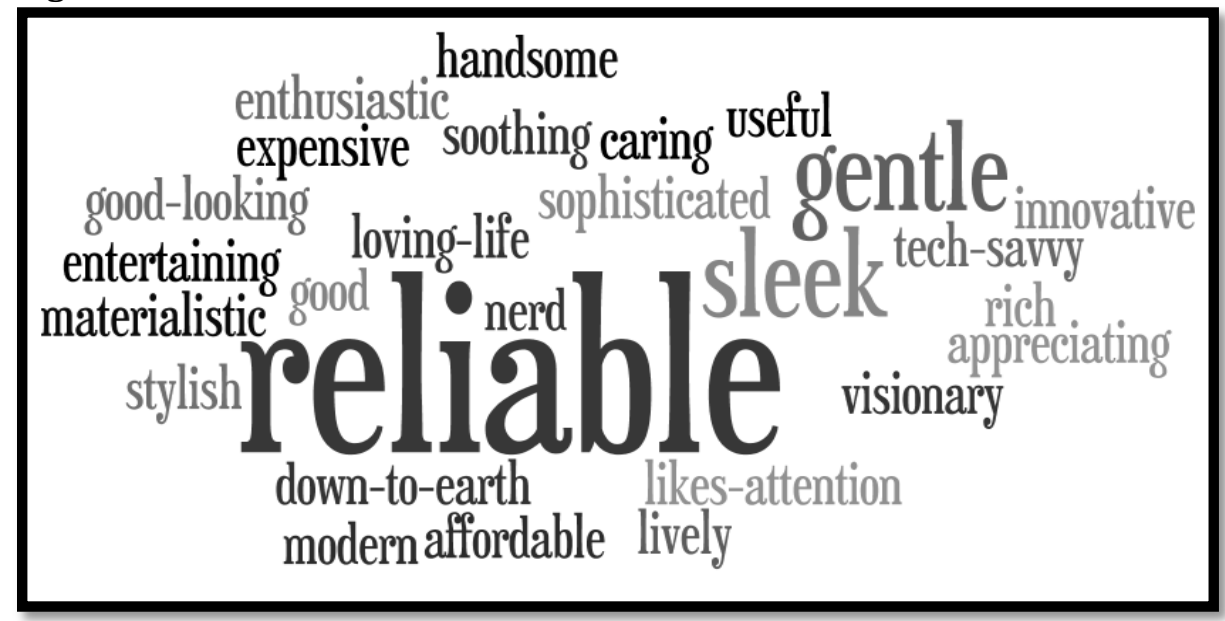

Figure 17: Toyota

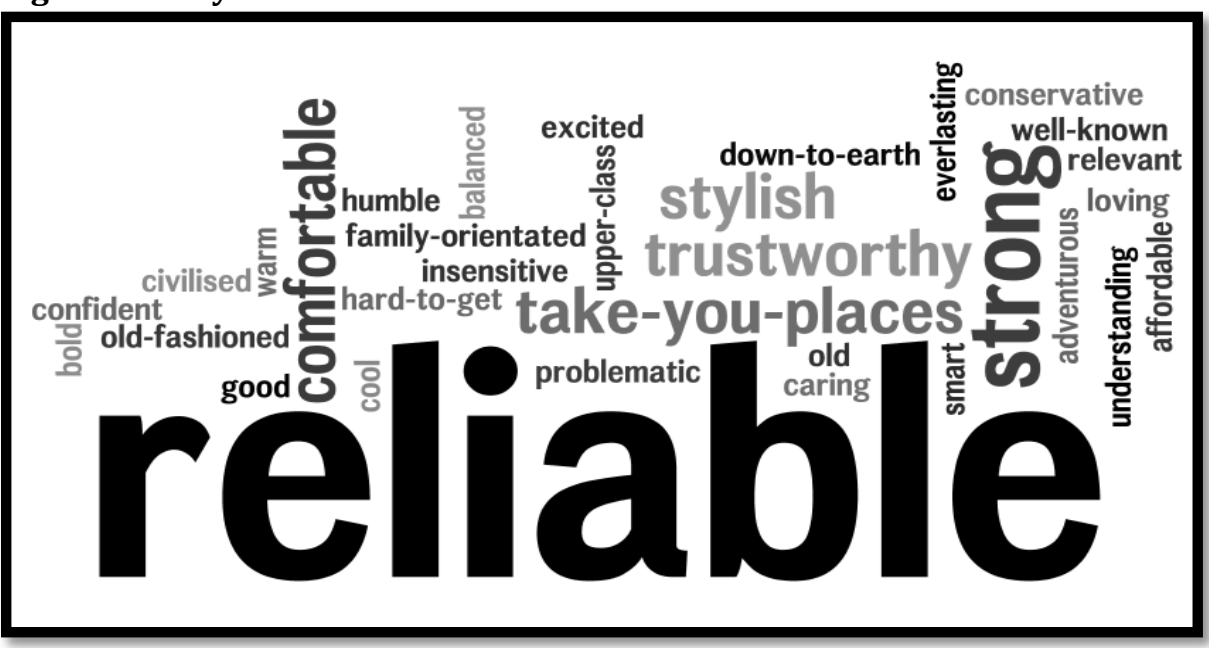




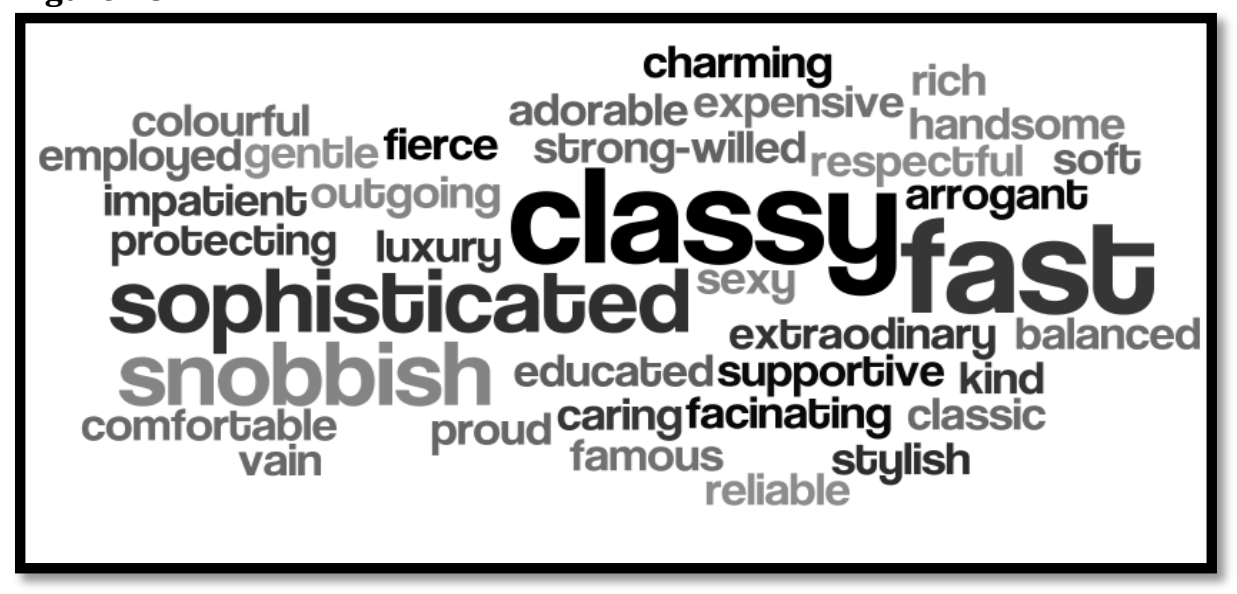

Discussion: The results obtained from this study give us a glimpse of how Generation $Y$ students perceive some of the top brands in South Africa. These results could be very insightful for the respective brand managers as they could compare these perceptions with their planned brand positioning. This could shed some light on possible alterations needed to the marketing strategy. A variety of traits were identified ranging from positive and negative aspects for some of the brands. The various brands could benefit by positioning the brand more towards the positive personality traits identified. The brand managers can also use the negative traits identified to redirect current marketing strategies that could be misinterpreted by some consumers. There is a definite reoccurrence of some traits at several of the brands. The reason for this might be because the study did make use of some traits ("gentle", "loving", "down-to-earth" and "reliable") as an example in the questionnaire. These traits were used to illustrate the concept of brand personality with non-symbolic brands ("soap", "coffee" and "polish"). These example traits may have influenced respondents to use these specific traits more often. The researcher also noticed that not all of the identified words can be classified as traits; this might be due to the fact that not all the respondents fully understood the concept of brand personality.

Limitations: These results are limited to a small sample and can thus not be perceived as the general perception of all consumers. The perceptions of the respondents might also be influenced by various factors other than marketing practices of the business such as personal experience with a sales person, word-ofmouth from friends and family regarding their experiences and product malfunction or bad after-sale service.

Recommendations: Future studies might consider analysing specific brand positioning strategies and advertisements of specific brands and compare these results with the outcomes of this study. Future studies should also consider utilising an established brand personality trait scale with a set of personality traits grouped in various constructs. Each of the brands can then be rated according to their descriptiveness of each of the traits. This will deliver more structured results which could be statistically analysed for reliability. Future studies might also consider studying the brand personality of utilarian products as well as services.

\section{Conclusion}

The contemporary market place is saturated with brands competing for consumers' attention, making it more challenging than ever before for marketers to differentiate their brands from that of their competitors. Creating a particular personality for a brand is well recognised as a marketing strategy to affect such a differentiation and create a strong brand image and, ultimately, higher brand preference and greater brand loyalty. This study indicated that consumers might have contradictory perceptions regarding brands. The study also emphasised that the perceived brand personality could be very different to the desired brand positioning of brands. Brand managers should be aware of the positive as well as negative personality traits associated with their brand as this might be useful when drafting future marketing strategies. 


\section{References}

Aaker, D. A. (1996). Measuring brand equity across products and markets. California management review, $38(3)$.

Aaker, J. L. (1997). Dimensions of Brand Personality. Journal of Market research, 34(3), 347-356.

Austin, J. R., Siguaw, J. A. \& Mattila, A. S. (2003). A re-examination of the generalizability of the Aaker brand personality measurement framework. Journal of Strategic Marketing, 11, 77-92.

Blythe, J. (2007). Advertising creatives and brand personality: A grounded theory perspective. Journal of Brand Management, 14(4), 284-294.

Chang, W. L. \& Lin, H. L. 2010. The impact of color traits on corporate branding. African Journal of Business Management, 4(15), 3344-3355.

Freling, T. H. \& Forbes, L. B. (2005). An examination of brand personality through methodological triangulation. Journal of Brand Management, 13(2), 148-162.

Govers, P. C. M. \& Mugge, R. (2004). 'I Love My Jeep, Because Its Tough Like Me': The Effect of ProductPersonality Congruence on Product Attachment, in Proceedings of the Fourth International Conference on Design and Emotion, ed. Aren Kurtgözü, Ankara, Turkey.

Heine, K. (2009). Using personal and online repertory grid methods for the development of a luxury brand personality. In 8th European Conference on Research Methodology for Business and Management Studies: University of Malta, Valletta, Malta, 22-23 June 2009: [proceedings] (p. 160). Academic Conferences Limited.

Heine, K. (2010). The Luxury Brand Personality Traits. In Thought Leaders International conference in Brand Management.

Kapferer, J. N. (2008). The New Strategic Brand Management, 4th ed., London: Kogan Page.

Lamb, C. W., Hair, J. F., McDaniel, C., Boshoff, C., Terblanche, N., Elliott, R. \& Klopper, H. (2010). Marketing. 4th ed. Cape Town: Oxford University Press South Africa: 504 p.

Mulyanegara, R. C., Tsarenko, Y. \& Anderson, A. (2009). The big five and brand personality: investigating the impact of consumer personality on preferences towards particular brand personality. Journal of Brand Management, 16(4), 234-247.

Opoko, R., Abratt, R. \& Pitt, L. (2006). Communicating brand personality: Are the websites doing the talking for the top South African Business Schools? Journal of Brand Management, 14(1/2), 20-39.

Ramaseshan, B. \& Tsao, H. (2007). Moderating effects of the brand concept on the relationship between brand personality and perceived quality. Journal of Brand Management, 14(6), 458-466.

Shiffman, L. G. \& Kanuk, L. L. (2010). Consumer Behaviour. 10th ed. New Jersey: Pearson.

Van Rekom, J., Jacobs, G., Verlegh, P. W. J. \& Podnar, K. (2006). Capturing the essence of a corporate brand personality: A Western brand in Eastern Europe. Journal of Brand Management, 14(1/2), 114-124. 